\title{
The Exchange Rate, the Trade Balance and The J-CURVE EFFECT IN SOUTH AFrica ${ }^{1}$
}

Eric Schaling

Wits Business School, University of the Witwatersrand

Alain Kabundi

South African Reserve Bank and University of Johannesburg

Accepted: May 2014

\begin{abstract}
We find that for the period 1994-2011 there is robust statistical evidence that, in the long run, net exports are boosted by a weaker real effective exchange rate. However, this effect does not hold in the short run We thus find empirical evidence supporting the J-curve effect for South Africa.
\end{abstract}

Key words: cointegration, exchange rates, J-curve, trade balance

\section{1}

\section{Introduction}

On 23 November 2010, government, under the leadership of Minister Ebrahim Patel, released the Framework of the New Economic Growth Path aimed at enhancing growth, employment creation and equity. The principal aim of the policy is to create five million jobs over the next 10 years.

This framework reflects government's commitment to prioritising employment creation in all economic policies. It identifies strategies that will enable South Africa to grow in a more equitable and inclusive manner while attaining South Africa's developmental agenda.

Importantly, the document underlying the New Growth Path recognizes the challenges of an uncompetitive currency and sets out clear steps whereby government can address the impact of the Rand on the economy. More specifically, on p. 2, the document discusses a trade-off between a competitive currency that supports growth in production, employment and exports and a stronger Rand that makes imports of capital and consumer goods cheaper. ${ }^{2}$ The 2011 industrial policy action plan (IPAP, 2011:39) also calls for a competitive exchange rate.
The South African Reserve Bank (SARB) stated its own position on the exchange rate as follows:

Exchange rate appreciation has been both a positive and a negative, on the one hand lowering South Africa's trade competitiveness, but also helping to dampen inflationary pressures given the influence of the exchange rate on consumer prices (SARB, 2012:6)

This shows that the debate about growth through competitiveness and exchange rate pass-through - the effects of a weaker Rand on inflation - is still alive and well. ${ }^{3}$

In this paper we find that, for the period 1994-2011, there is robust statistical evidence that, in the long run, net exports are boosted by a weaker real effective exchange rate. However, this effect does not hold in the short-run. We thus find empirical evidence supporting the J-curve effect for South Africa.

The remainder of this paper is organized as follows. Section 2 outlines some previous empirical evidence. Our econometric model for South Africa regarding the exchange rate and the trade balance is presented in Section 3 . Section 4 concludes. 
2

\section{The exchange rate and the trade balance: A review of some previous studies}

\subsection{Exchange rate pass-through}

A depreciation of the Rand may have adverse effects on South African consumer price inflation. This link is known as exchange rate pass-through, which in empirical studies is typically analyzed in three ways. ${ }^{4}$

The first approach is to explore the direct link between the nominal (or nominal effective) exchange rate and CPI inflation. This is the route followed by, inter alia, Razafimahefa (2012). He analyzes the passthrough of the nominal effective exchange rate to domestic prices in sub-Saharan African countries from 1985 to 2008 . He finds that the average elasticity is estimated at 0.4 . Half of the increase (of domestic prices in response to a depreciation) occurs within the first quarter following the exchange rate change, and the full impact generally takes place within four quarters. For South Africa, the impact of a 10 per cent depreciation of the Rand after four quarters is 1.31 per cent ( 1.6 per cent after eight quarters). This is in line with his finding that higher income countries have a lower exchange rate pass-through.

The second approach is to investigate the relationship between the nominal exchange rate and import prices (where the latter would feed into the CPI). This is the avenue followed by Aron, Farrell, Muellbauer and Sinclair (2012). They examine exchange rate pass-through to the monthly import price index in South Africa during 1980-2009. They find that pass-through is about 50 per cent in a year and 30 per cent in six months. Johansen analysis broadly supports these short-run results but implies lower longrun pass-through.

A third approach is to assess both the relationships between exchange rate movements, prices of imported inputs and domestic inflation. This is obviously the most complex modeling strategy and is employed by Rigabon (2007). It can be motivated by realizing that the pass-through is a function of the monetary policy framework. Rigabon evaluates how credible the SARB's inflation targeting is to shocks to the nominal exchange rate. His argument is that a credible central bank that announces an inflation target is 100 per cent credible if, in the presence of a transitory exchange rate shock, the target is unaffected, and the central bank is therefore able to keep it. This would be the case of zero pass-through. On the other hand, a non-credible central bank implies that nominal exchange rate devaluation will be accommodated by the central bank with further domestic inflation. The definition he uses in his paper is: How many of the nominal exchange rate movements are ultimately accommodated by the monetary authority? So, by looking at the change in the pass-through, he is able to detect the gains in credibility. Rigabon concludes that the large reduction in the pass-through experienced in South Africa is the outcome of a large gain in the inflation targeting regime's credibility. ${ }^{5}$

\subsection{The link between exchange rate depreciation and the trade balance}

Edwards and Lawrence (2006) estimate a simple trade balance equation using a panel of data for 44 manufacturing industries for 19902002. They find that a depreciation of the bilateral real exchange rate vis-à-vis the USA improves the trade balance, but mainly for noncommodity manufacturers. More specifically, a 1 per cent depreciation is estimated to raise the value of exports relative to imports by approximately 0.7 per cent.

Lawrence and Garlick (2008) review the theoretical and empirical relationship between the exchange rate and trade flows in South Africa. Trade volumes are found to be sensitive to real exchange rate movements, but nominal depreciations have a limited long-run impact on trade volumes and the trade balance, as real effects are offset by domestic inflation. As a consequence, policy should not focus on the exchange rate, but on the fundamental determinants of the profitability and competitiveness of domestic exporters and import competing industries: productivity enhancement, infrastructure, constraints to business operations and production costs, including labour costs. They mention that the short-run dynamics of the trade balance and the possibility of a Jcurve effect for South Africa are not fully understood. 
Finally, Ncube and Ndou (2013) compare the effects of contractionary monetary policy and exchange rate appreciation shocks on the South African trade balance using recursive and sign-restriction VAR approaches. They find that a trade-weighted exchange rate appreciation worsens the trade balance as a percentage of GDP for longer than contractionary monetary policy shocks.

In the next section we try to shed light on the research question posed by Lawrence and Garlick (2008) and address the short-run dynamics of the trade balance and the J-curve effect for South Africa.

3

\section{Empirical analysis}

\subsection{Data and descriptive statistics}

The above literature review indicates that a weaker Rand tends to push up the inflation rate. However, owing to the weaker currency, there may be expenditure switching effects that boost net exports. In the latter case - if SA exports are invoiced in Rand, so that we have producer currency pricing - this real depreciation will increase South Africa's international price competitiveness. ${ }^{6}$ Therefore, as mentioned by the SARB, there appear to be 'positives' and 'negatives', a weaker exchange rate increases domestic inflation, which has an adverse effect on the economy, but with increased price competitiveness may increase net exports and consequently SA's GDP. ${ }^{7}$

Our analysis focuses not so much on the pass-through $^{8}$ but on the 'positive' of a real depreciation.

We now present our empirical work on the link between price competitiveness - the real effective exchange rate of the Rand - and the trade balance in South Africa.

We use quarterly data from 1994Q1 to 2011Q4 $(T=72)$ which coincides with the new dispensation in South Africa brought about by the first democratic election. The analysis uses the real effective exchange rate of the Rand (REER), South African Real Gross Domestic Product (SAGDP), and the trade balance (TRB) obtained as the logarithm of the ratio of real exports of goods and services to real imports of goods and services. All these series were obtained from the South African Reserve Bank (SARB). In addition, we use United States (US) real GDP (USGDP), obtained from the International Financial Statistics (IFS) of the International Monetary Fund (IMF), as a proxy for foreign economic activity. All series are in natural logarithms and are seasonally adjusted (except the REER) using the X11 filter based on an $\operatorname{AR}(4)$ process. ${ }^{9}$

\subsection{Model and test procedure}

We use the DF-GLS test proposed by Elliot, Rothenberg and Stock (1996) and the KPSS test developed by Kwiatowski, Phillips, Schmidt and Shin (1992) to assess the degree of integration of all the series. The unit root tests included a constant and a deterministic trend. The number of lags is selected using the Schwarz information criterion, so that no serial correlation is left in the residuals. The results of the unit root tests, depicted in Table 1, indicate that all series are integrated of order one. The observation of the series in Figure 1 confirms the findings of unit root tests in that these variables exhibit a trend. It implies that a simple regression using all these variables in levels is spurious. To solve this issue, we test for the possibility of cointegration using the Johansen test developed by Johansen (1991).

Table 1

Unit root tests

\begin{tabular}{|l|c|c|c|c|}
\cline { 2 - 5 } \multicolumn{1}{c|}{} & \multicolumn{2}{c|}{ DF-GLS } & \multicolumn{2}{c|}{ KPSS } \\
\cline { 2 - 5 } \multicolumn{1}{c|}{} & Level & 1st difference & Level & 1st difference \\
\hline TRB & -1.31 & $-4.44^{* * *}$ & 0.22 & $0.08^{* * *}$ \\
\hline SAGDP & -1.78 & $-4.72^{* * *}$ & 0.16 & $0.10^{* * * *}$ \\
\hline REER & -2.51 & $-8.68^{* * *}$ & 0.15 & $0.04^{* * *}$ \\
\hline USGDP & -0.99 & $-5.13^{* * *}$ & 0.24 & $0.05^{* * *}$ \\
\hline
\end{tabular}


We use US GDP as an exogenous variable and the results in Table 2 for both the trace statistic and maximum eigenvalue statistic point to one cointegrating equation, rejecting the null hypothesis of zero cointegration at the 5 per cent level of significance. The appropriate empirical estimation of the trade balance is therefore a Vector Error Correction Model (VECM), which reconciles short-term dynamics with a long-term equilibrium relationship between these variables.

Table 2

Johansen cointegration test

\begin{tabular}{|l|c|c|}
\hline \multicolumn{1}{|c|}{ Null } & Eigenvalue & Trace \\
\hline$r=0$ & $0.25^{* *}$ & $32.87^{* *}$ \\
\hline$r=1$ & 0.16 & 13.05 \\
\hline$r=2$ & 0.02 & 12.29 \\
\hline \multicolumn{2}{|c|}{ Note ***** } \\
\hline
\end{tabular}

Note $* * * * * *$, indicate significant at 10 per cent, 5 per cent, and 1 per cent, respectively

Figure 1

Variables

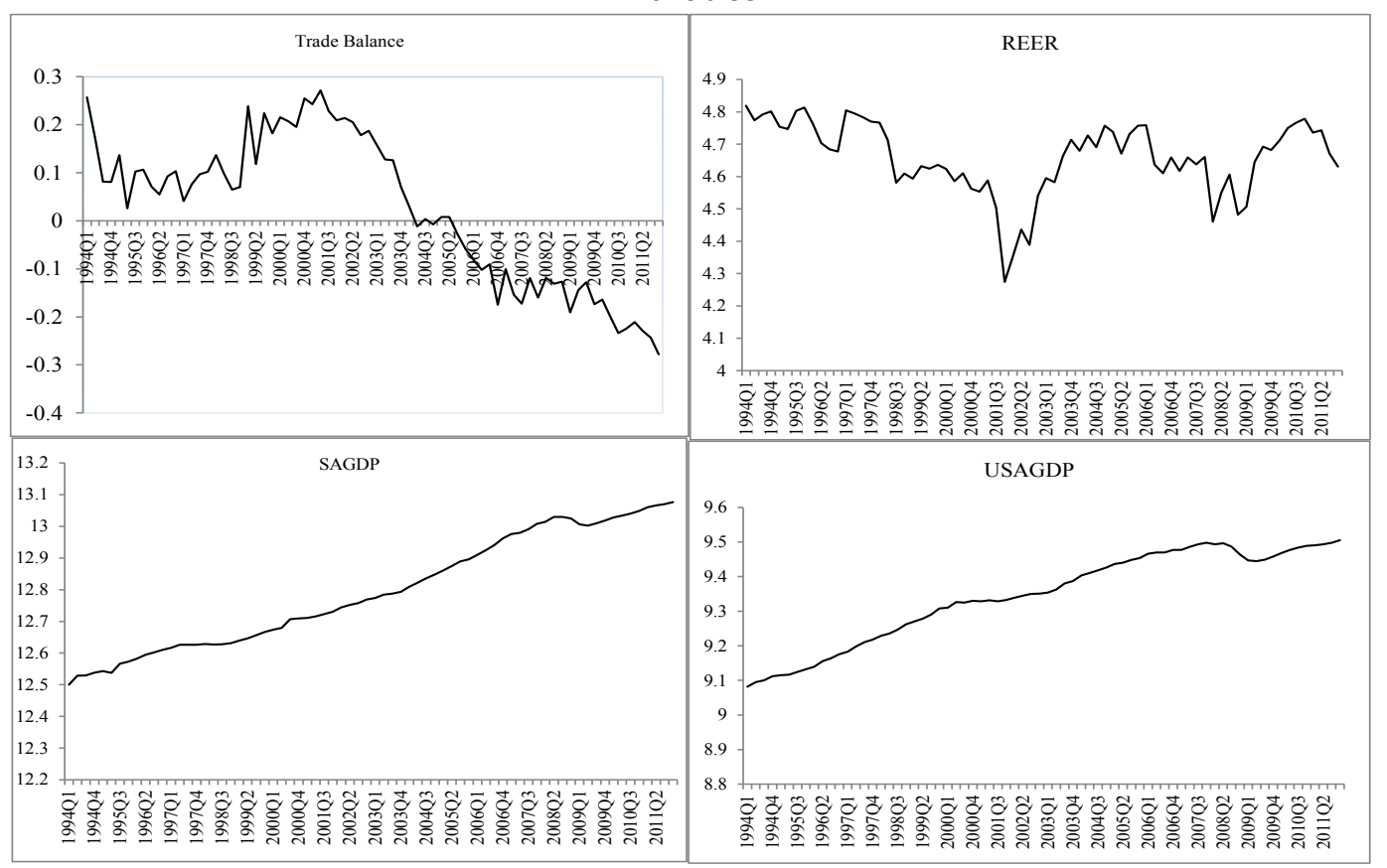

\subsection{Empirical results}

In this section we estimate the following Vector Error Correction Model for the trade balance in South Africa. The long-run determinants of the trade balance in South Africa are as follows:

$$
\begin{gathered}
T R B_{t}=-12.09-1.38 S A G D P_{t}-0.67 \text { REER }_{t}+0.93 U S G D P_{t} \\
(0.19) \quad(0.10)
\end{gathered}
$$

where values in parentheses are standard errors. There is evidence of a long-term equilibrium relationship between the trade balance on one hand and domestic income, the real effective exchange rate, and foreign income on the other hand. The relationship is validated by a negative and significant error correcting factor of -0.38 (see equation 1 ). We 
control with a dummy variable to account for the change in the monetary policy regime of inflation targeting (i.e. pre and post February 2000 ), but the coefficient is statistically insignificant. ${ }^{10}$ After a year, the total adjustment is 85 per cent, which is relatively slow.

Ceteris paribus, a rise in domestic income associated with an increase in the demand for imported goods and services causes a deterioration of the trade balance. Specifically, a 1 per cent increase in SA GDP results in a 1.38 per cent decrease in the trade balance. ${ }^{11}$

In contrast, an increase in US GDP, as a proxy for foreign economic activity, encourages exports from South Africa to the rest of the world (ROW). Consequently the trade balance improves. $^{12}$

The results in (1) show that a 1 per cent in US GDP improves the trade balance by 0.93 per cent, which is less than the deterioration caused by a similar performance domestically. We can conclude that the SA economy is substantially linked to economic growth abroad. Consequently, deterioration in the output of foreign economies has a negative impact on the SA trade balance.
A depreciation of the South African Rand would be likely to improve exports and slow down imports, thereby improving the trade balance. If this is the case, then we have empirical support for the trade-off mentioned earlier: a weaker Rand has adverse passthrough effects on inflation, but this could somehow be counterbalanced by an improvement in the trade balance, thereby increasing SA GDP.

This analysis is strongly supported by the data. Equation (1) reports that, in the long run, a 1 per cent depreciation of the Rand improves the trade balance by 0.67 per cent. ${ }^{13}$

However, as mentioned before in our discussion on exchange rate pass-through, depreciating the Rand has direct effects on inflation. Therefore, in trying to improve the trade balance, the policymaker might inadvertently create another problem, that of a higher inflation rate, which on its own is a difficult task to solve. For a model that outlines the effects of the real exchange rate on inflation, see Fedderke and Schaling (2005).

The VECM results of the trade balance equation are as follows:

$$
\begin{aligned}
& \Delta T R B_{t}=-0.01-0.26 \Delta T R B_{t-1}-0.37 \Delta S A G D P_{t-1}+0.19 \Delta R E E R_{t-1}+1.0 .3 \Delta U S G D P_{t-1} \\
& \begin{array}{llll}
(0.10) & (0.68) & (0.08) & (0.72)
\end{array} \\
& -0.38\left(\text { TRB }_{t-1}+1.38 S A G D P_{t-1}+0.67 \text { REER }_{t-1}-0.93 U S G D P_{t-1}\right) \\
& (0.09) \quad(0.19)
\end{aligned}
$$

where $\Delta$ is the first difference. According to the results we have $\bar{R}^{2}=0.32$, the BreuschGodfrey test does not reject the null hypothesis of no autocorrelation in the residuals (with a $p$ value of 0.11 ), and the residuals are homescedastic ( $p$-value of the White test is 0.13 ).

The results in 2 are slightly different from the long-run results in 1. Most of the coefficients of the short-term variables - the series in first differences - are statistically insignificant. For example, a 1 per cent rise in SA GDP results in a 0.37 per cent decrease in the trade balance. However, this impact is not statistically significant. Thus, the trade balance is insensitive to domestic income in the short term. Similarly, foreign income has no direct effects on the trade balance in the short run. In contrast, the real effective exchange rate depicts a positive sign and significant effects in the short run. This means that, in the short run, a real depreciation has the opposite effect to that in the long run. We know from equation 1 that, in the long run, a 1 per cent real deprecation improves the trade balance by 0.67 per cent. However, from equation 2 we see that, in the short run, a 1 per cent real depreciation worsens the trade balance by 0.19 per cent. Thus, a policy aiming at promoting growth by means of a real depreciation is not successful in the short term. In the context of earlier empirical work on the link between exchange rates and the trade balance, this is called the J-curve effect, where, as a result of a depreciation, the trade balance may initially get worse before it gets better. ${ }^{14}$

In figure 2 we show some impulse responses following a 0.06 per cent rise (appreciation) in the REER. It is evident that the trade balance (TRB) decreases and reaches the minimum of -0.02 per cent after the third 
quarter, SA GDP decreases and reaches the minimum of -0.008 per cent after a year, while
US GDP increases and reaches the maximum of 0.006 per cent in quarter 2 .

Figure 2

Impulse responses in the REER

Response of REER to REER
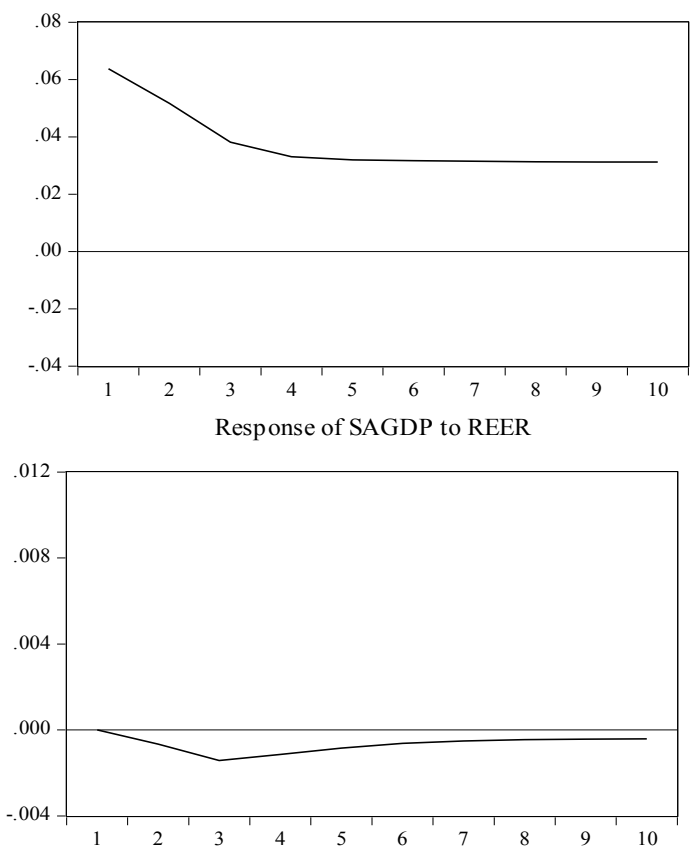

Finally, in Table 3 we show variance decompositions; the exchange rate shock explains 68 per cent of changes in the
Response of TRB to REER
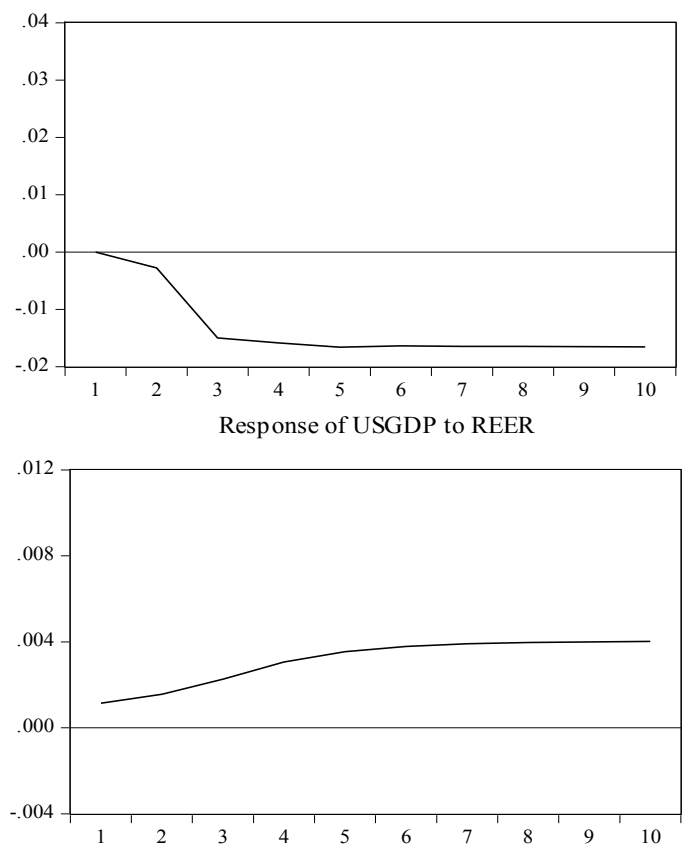

exchange rate, 28 per cent of variation in the TRB, 3 per cent changes in the SA GDP, and 0.2 per cent changes in the US GDP.

Table 3

Variance decomposition of an exchange rate stock

\begin{tabular}{|l|r|}
\hline REER & 68.342 \\
\hline TRB & 28.768 \\
\hline SAGDP & 2.721 \\
\hline USGDP & 0.169 \\
\hline
\end{tabular}

4

\section{Conclusions}

As pointed out in the introduction, a real depreciation may have both positive and negative effects. The negative effects have to do with the so-called pass-through of an exchange rate depreciation in inflation. A real depreciation increases SA's inflation rate. An overview of the relevant empirical evidence was presented earlier.

However, there may be some compensation in terms of increased price competitiveness and an associated improvement in the trade balance. We find no evidence of such 'positives' in the short run. This is because, in the short run for South Africa, there is evidence of the existence of the so-called Jcurve effect; following a real depreciation there is an initial (short-run) deterioration in the real trade balance.

However, we find evidence that, in the long run, a real depreciation does improve the trade balance. 


\section{Endnotes}

1 The views expressed in this article are those of the authors and do not necessarily represent those of the South African Reserve Bank or South African Reserve bank policy.

2 See the website of the New Growth Path under South African Government Information, i.e. http://www.info.gov.za/aboutgovt/programmes/new-growth-path/index.html. For the underlying document see http://www.info.gov.za/view/DownloadFileAction?id=135748. In what follows, in line with the New Growth Path, we will refer to a competitive exchange rate as one that supports growth in production, employment and exports.

3 According to Stanlib's Economic Focus (http://www.stanlib.com/EconomicFocus/Pages/SANationalDevelopmentPlan.aspx) in the National Development Plan [National Planning Commission (2011)] there is no belief expressed that a weaker exchange rate is the panacea to South Africa's economic success. It points out that South Africa's present economic capabilities do not allow greater control over the exchange rate, although reducing the volatility is a critical challenge that requires attention.

4 It could be that the pass-through is close to zero. This depends on many factors, such as menu costs, import composition, consumption composition and substitution effects.

5 For a study on the credibility of the SARB's inflation targeting regime, see Kabundi and Schaling (2013).

6 If our exports are priced in local currency - in terms of the destination country of our exports (LCP) - US dollars, say, then a rand depreciation would boost the export industry's profits but would not induce greater demand for South African goods or services (expenditure switching). The latter may happen if our exports are invoiced in rand, called producer currency pricing (PCP). For a recent article that compares LCP and PCP see Fende et al. (2008)

7 However, there may also be a Phillips curve effect whereby improved SA GDP could push inflation further up.

8 We leave this for further research. We could include CPI or PPI in the analysis and maybe add one of them to the VECM Then one could with the help of impulse-responses consider the effect of REER on inflation.

9 This is the method used to seasonally adjusted series.

10 The error correcting factor is significant at the 1 per cent level (see equation (2) on p604)

11 Yusoff (2007) finds the opposite for Malaysia. The trade balance increases by 0.36 per cent following a 1 per cent rise in domestic GDP.

12 The results do not change when we include G7-GDP, instead of US GDP, as a proxy for foreign economic activity (the results are available upon request).

13 Broadly speaking, this suggests that the so-called Marshall-Lerner condition holds for South Africa. In the context of separate import and export functions - an approach we do not follow as more recent empirical work has relied increasingly on cointegration analysis - the Marshall-Lerner condition states that the sum of the elasticities of export supply and import demand with respect to the real exchange rate must exceed unity for the trade balance to improve. The results in this paper are supported by those of Edwards and Lawrence (2006), who find that a 1 per cent depreciation is estimated to raise the value of exports relative to imports by approximately 0.7 per cent.

14 For empirical evidence on the J-curve effect, see, for instance, Wilson (2001).

\section{References}

ARON, J., FARRELL, G., MUELLBAUER, J. \& SINCLAIR, P. 2012. Exchange rate pass-through to import prices and monetary policy in South Africa. South African Reserve Bank Working Paper, WP/12/08, September.

EDWARDS, L. \& LAWRENCE, R. 2006. South African trade policy matters: Trade performance \& trade policy. Harvard Centre for International Development Working Paper, 135.

ELLIOTT, G., ROTHENBERG, J. \& STOCK, J. 1996. Efficient tests for an autoregressive unit root. Econometrica, 64:813-36.

FEDDERKE, J. \& SCHALING, E. 2005. Modeling inflation in South Africa: A multivariate cointegration analysis. South African Journal of Economics, 73(1):79-92.

FENDE, R, FRENKE, M. \& SWANKE, C. 2008. Local currency pricing versus producer currency pricing: Direct evidence from German exporters, German Economic Review, 9:160-179.

INDUSTRIAL POLICY ACTION PLAN. 2011. 2011/12-2013/14 Economic sectors and employment cluster, February.

JOHANSEN, S. 1991. Estimation and hypothesis testing of cointegration vectors in Gaussian vector autoregressive models. Econometrica, 59:1551-1580.

KABUNDI. A. \& SCHALING, E. 2013. Inflation and inflation expectations in South Africa: An attempt at explanation. South African Journal of Economics, June:1-10.

KWIATOWSKI, D., P.C.B. PHILLIPS, P. SCHMIDT, \& Y. SHIN 1992. Testing the null hypothesis of stationarity against the alternative of a unit root: How sure are we that economic time series have a unit root? Journal of Econometrics, 54:159-78.

LAWRENCE E.J. \& GARLICK, R. 2008. Trade flows and the exchange rate in South Africa. Available at: http://mpra.ub.uni-muenchen.de/36666/. 
NATIONAL PLANNING COMMISSION. 2011. National development plan. Available at: http://www.npconline.co.za/medialib/downloads/home/NPC\%20National\%20Development\%20Plan\%20Visi on $\% 202030 \% 20$-lo-res.pdf.

NCUBE, M. \& NDOU, E. 2013. Monetary policy and exchange rate shocks on the South African trade balance. African Development Bank Working Paper Series, No 169, Tunis, Tunisia.

RAZAFIMAHEFA, I.F. 2012. Exchange rate pass-through in sub-Saharan African economies and its determinants. IMF Working Paper, WP/12/141, June.

RIGABON, R. 2007. Through the pass-through: Measuring central bank credibility, CID Working Paper, No 143, March.

SARB. 2012. South African monetary policy in the context of central banking developments abroad. Address by Daniel Mminele, Deputy Governor of the South African Reserve Bank, at the Tradition Dinner, Johannesburg, 28 November.

WILSON, P. 2001. Exchange rates and the trade balance for dynamic Asian economies: does the J-curve exist for Singapore, Malyasia, and Korea? Open Economies Review, 12(June):389-413.

YUSOFF, M.B. 2007. The Malaysian real trade balance and the real exchange rate. International Review of Applied Economics, 21(5):655-667. 